\title{
The American Mind Is Dead, Long Live the American Mind - CORRIGENDUM
}

\author{
Amy Kittelstrom* \\ Department of History, Sonoma State University \\ ${ }^{\star}$ Corresponding author. E-mail: akittelstrom@gmail.com
}

In the original version of this article, footnote 9 and the clause it supported were erroneous; these have now been replaced with alternate wording. The author apologises for this error.

\section{Reference}

Kittelstrom A (2020). The American Mind Is Dead, Long Live the American Mind. Modern Intellectual History 1-12. https://doi.org/10.1017/S147924432000013X

Cite this article: Kittelstrom A (2021). The American Mind Is Dead, Long Live the American Mind CORRIGENDUM. Modern Intellectual History 18, 897. https://doi.org/10.1017/S1479244320000177

(C) The Author(s) 2020. Published by Cambridge University Press 